\title{
EVALUATION OF ANTIMICROBIAL AND SYNERGISTIC ANTIMICROBIAL PROPERTIES OF PTEROCARPUS SANTALINUS
}

\section{SAVAN DONGA, POOJA MOTERIYA, SUMITRA CHANDA*}

Department of Biosciences, Phytochemical, Pharmacological and Microbiological Laboratory, Saurashtra University, Rajkot - 360 005, Gujarat, India. Email: svchanda@gmail.com

Received: 24 June 2017, Revised and Accepted: 24 July 2017

\section{ABSTRACT}

Objectives: The aim of the present study was to evaluate antibacterial and synergistic antimicrobial properties of leaf, stem, and bark of Pterocarpus santalinus.

Methods: The extraction was done by decoction method. The antimicrobial activity was evaluated by agar well diffusion assay, and the synergistic antimicrobial activity was evaluated by agar disc diffusion assay.

Results: The synergistic activity was studied with plant extracts plus antibiotics, namely, ampicillin, polymyxin-B, clotrimazole, and fluconazole.

Conclusions: Among the three parts, the best antimicrobial activity was shown by bark extract. All the three parts showed synergistic antimicrobial activity with antibiotics, but their levels varied. The results suggest that all the three parts enhance the antimicrobial efficacy of the antibiotics against some microorganisms and hence can be developed as a new therapeutic weapon against infectious diseases.

Keywords: Pterocarpus santalinus, Synergistic antimicrobial activity, Antibiotics, Bark, Fluconazole.

(C) 2017 The Authors. Published by Innovare Academic Sciences Pvt Ltd. This is an open access article under the CC BY license (http://creativecommons. org/licenses/by/4. 0/) DOI: http://dx.doi.org/10.22159/ajpcr.2017.v10i11.20939

\section{INTRODUCTION}

Asian countries are famous for traditional medical practices such as Ayurveda, Unani, and Siddha [1]. Medicinal plants have been a valuable source of natural active constituents that products used for maintaining human health and treatment of many human diseases [2]. Many of the plant materials used in traditional medicine are readily available in rural areas. According to the World Health Organization, $80 \%$ of developed countries use traditional medicine [3]. Plants are easily available, renewable in nature, not expensive, and have fewer side effects and better patient tolerance. Herbal medicine is a traditional or folk medicinal practice based on the use of plants' seeds, berries, roots, leaves, bark, and flowers extracts as medicine [4]. It is cheaper than modern medicine. Medicinal plants show various activities like antioxidant, antimicrobial, antitumor, antimutagenic, anticarcinogenic, anticancer, anti-ulcer, antiurolithiatic, anti-inflammation, antidiabetic, diuretic, etc.

Plants are a good source of many kinds of economically important compounds such as phenolic compounds, nitrogen containing compounds, vitamins, and minerals. Phytochemical constituents are the chemical compounds formed during the plants normal metabolic growth, and these are potential bioactive compounds which are precursors for the synthesis of useful drugs [5]. Plants are rich in a wide variety of secondary metabolites such as phenolics, tannins, terpenoids, alkaloids, saponins, glycosides, and flavonoids [6,7].

Microbial infections constitute a major public health problem in developing countries. In the recent years, the development of resistance of pathogens against antibiotics has become a difficult issue caused by the indiscriminate use of antibiotics. Antibiotics have been called miracle drugs, but more than 60 years of use, the efficacy of current antimicrobial agents has been reduced due to the continuing emergence of drug-resistant organisms and the adaptations by microbial pathogens to commonly used antimicrobials $[8,9]$.

Therefore, the demand for new and effective antimicrobial agents with broad-spectrum activities from natural sources is increasing day by day.
In view of this, the search for new antimicrobial agents from medicinal plants is even more urgent in the countries like India. Infectious diseases of bacterial origin are not only rampant but also the causative agents are also developing an increasing resistance against many of the commonly used antibiotics. Considering the high costs of the synthetic drugs and their various side effects, the search for alternative products from plants used in folklore medicine is further justified. The plantbased antibacterial compounds would be ideal to combat this problem. Some of the promising plants with antimicrobial properties are given in Table 1.

Antibiotics that work today may not work tomorrow. As resistance to old antibiotics spreads, new antimicrobial agents have to be discovered if the problem is to be contained. Unlike synthetic drugs, antimicrobials of plant origin are not associated with side effects and have a great therapeutic potential to heal many infectious diseases. Sometimes, the use of single antibiotic does not produce the desired inhibitory effects, and to overcome this, a combination of drugs often exercises their synergistic effect. Synergism is defined as a positive interaction created when two agents are combined and together they exert an inhibitory effect that is greater than the sum of their individual effects. The synergism is a new concept in developing agents for antibacterial, antioxidant, and also for anticancer activity. The new approach is combination therapy or synergistic therapy against resistant microorganisms which may lead to new ways of treating infectious diseases.

The aim of the present work was to evaluate antimicrobial and synergistic antimicrobial properties of Pterocarpus santalinus leaf, stem, and bark extracts.

\section{Plant description [10]}

P. santalinus Linn. $f$.

- $\quad$ Scientific name: P. santalinus Linn. f.

- Family: Fabaceae

- Description: P. santalinus is a light-demanding small tree, growing to

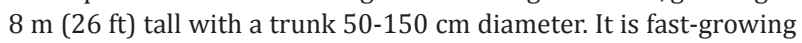


Table 1: List of some medicinal plants, their family, and microorganism used for antimicrobial activity

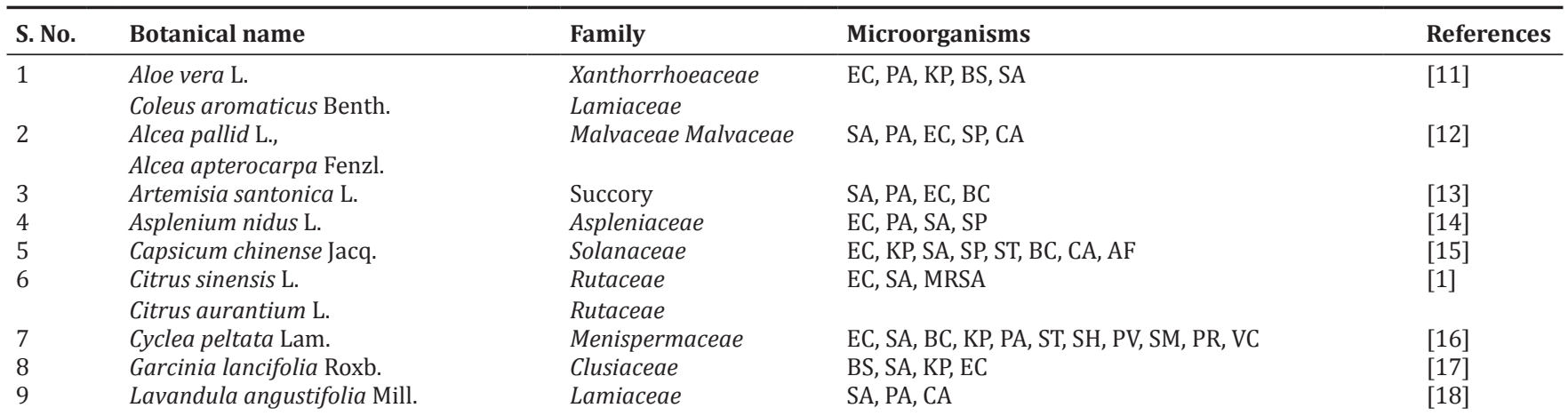

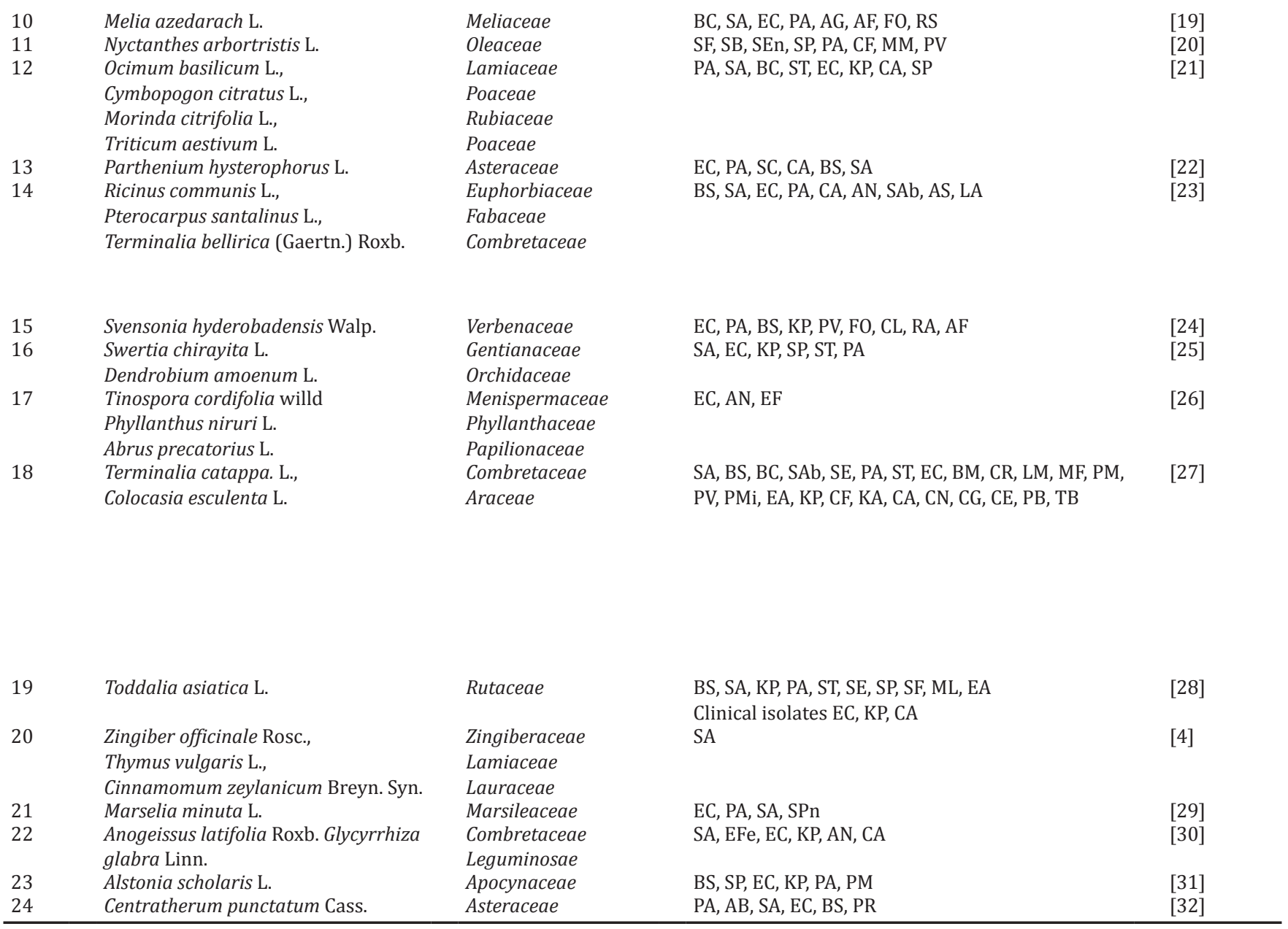

AB: Acinetobacter baumannii, AF: Aspergillus flavus, AN: Aspergillus niger, AS: Alternaria solani, BC: Bacillus cereus, BM: Bacillus megaterium, BS: Bacillus subtilis, CA: Candida albicans, CE: Candida epicola, CF: Citrobacter freundii, CG: Candida glabrata, CL: Curvularia lunata, CN: Cryptococcus neoformans, CR: Corallium rubrum, EA: Enterobacter aerogenes, EC: Escherichia coli, EF: Epidermophyton floccosum, EFe: Enterococcus faecalis, FO: Fusarium oxysporum, KA: Klebsiella aerogenes, KP: Klebsiella pneumoniae, LA: Lasiodiplodia abnormis, LM: Listeria monocytogenes, MF: Myotis flavus, MM: Morganella morganii, ML: Micrococcus luteus, MRSA: Methicillin-resistant Staphylococcus aureus, PA: Pseudomonas aeruginosa, PM: Proteus morganii, PMi: Proteus mirabilis, PR: Providencia rettgiri, PV: Proteus vulgaris, RA: Rhizopus arrhizus, RS: Rhizopus stolonifer, SA: Staphylococcus aureus, SAb: Salmonella abony, SB: Shigella boydii, SC: Saccharomyces cerevisiae, SE: Staphylococcus epidermidis, SEn: Salmonella enteritidis, SF: Shigella flexneri, SH: Staphylococcus haemolyticus, SM: Serratia marcescens, SP: Streptococcus pyogenes, SPa: Salmonella paratyphi, SPn: Streptococcus pneumonia, ST: Salmonella typhimurium, TB: Trichosporon beigelii, VC: Vibrio cholerae

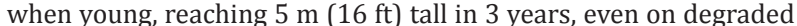
soils. It is not frost tolerant, being killed by temperatures of $-1^{\circ} \mathrm{C}$. The leaves are alternate, 3-9 cm long, trifoliate with three leaflets. The flowers are produced in short racemes. The fruit is a pod 6-9 cm long containing one or two seeds.
- Vernacular name: Rakta Chandan

- Part used: Leaves, stem, and bark

- Uses: It is an astringent and a cooling agent and is used in several skincare preparations. It is used in the treatment of pimples, acne, and wrinkles. It is also used internally in chronic bronchitis, 
gonorrhea and gleet, and chronic cystitis with benzoic and boric acids. Much used as a perfume for different purposes. The wood is used for making fancy articles and is much carved. It has been used in Ayurvedic medicine as an antiseptic, wound-healing agent and in anti-acne treatment

- Commercial utility: Red sandalwood with wavy grain margins sells at higher prices than the standard wood.

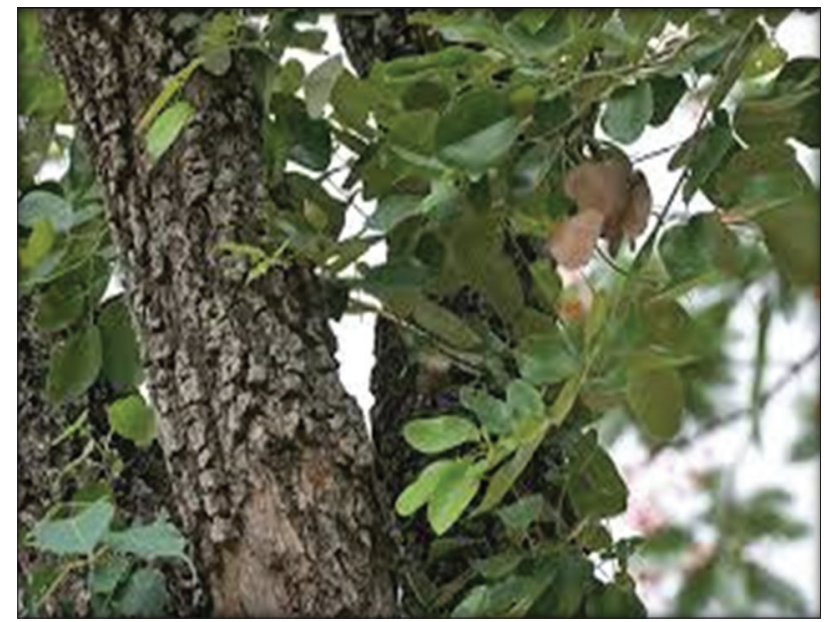

\section{METHODS}

\section{Plant collection}

The leaf, stem, and bark of $P$. santalinus Linn. f. were collected in August 2015 from Surat, Gujarat, India. They were thoroughly washed with tap water and dried under shade. The dried plant parts were homogenized to a fine powder and stored in airtight bottles and later used for extraction.

\section{Extraction: Decoction method}

About $5 \mathrm{~g}$ of dried powder of leaf, stem, and bark was extracted with $100 \mathrm{ml}$ of deionized water at $100^{\circ} \mathrm{C}$ for 30 minutes in a water bath [33]. It was filtered with 8 layers of muslin cloth and centrifuged at $5000 \mathrm{rpm}$ in centrifuge (Remi centrifuge, India) for 10 minutes. The supernatant was collected, and the solvent was evaporated to dryness. The residue was weighed to obtain extractive yield, and it was stored in an airtight bottle at $4^{\circ} \mathrm{C}$.

\section{Determination of total phenol content}

The amount of total phenol content was determined by Folin-Ciocalteu's reagent method [34]. The extract $0.5 \mathrm{ml}$ and $0.1 \mathrm{ml}$ of Folin-Ciocalteu's reagent $(0.5 \mathrm{~N})$ was mixed, and the mixture was incubated at room temperature for $15 \mathrm{~min}$. Then, $2.5 \mathrm{ml}$ of sodium carbonate $(2 \mathrm{M})$ solution was added and further incubated for $30 \mathrm{~min}$ at room temperature, and the absorbance was measured at $760 \mathrm{~nm}$ (Systronics, India), against a blank sample. Total phenol content is expressed in terms of gallic acid equivalent ( $\mathrm{mg} \mathrm{g}^{-1}$ of extracted compound). The assay was carried out in triplicate, and the mean values with \pm standard error of mean are presented.

\section{Antimicrobial activity}

Antimicrobial activity was measured by agar well diffusion method against Gram-positive bacteria, Gram-negative bacteria, and fungal strains.

\section{Microorganisms tested}

The microorganisms were obtained from the National Chemical Laboratory, Pune, India. The microorganisms were maintained at $4^{\circ} \mathrm{C}$. The bacteria and fungi were maintained on nutrient agar and MGYP medium (Hi Media, India), respectively. The Gram-positive bacteria studied were Bacilluscereus (BC) ATCC11778, Bacillussubtilis ATCC6633, Staphylococcus aureus (SA) ATCC29737, and Corynebacterium rubrum ATCC14898. The Gram-negative bacteria were Escherichia coli (EC)
NCIM2931, Pseudomonas aeruginosa (PA) ATCC27S53, Salmonella typhimurium ATCC23564, and Klebsiella pneumoniae (KP) NCIM2719. Yeasts were Candida albicans (CA) ATCC209l, Cryptococcus neoformans (CN) NCIM3542, Candida glabrata (CG) NCIM3448, and Candida epicola (CN) NCIMB367 and four clinical fungal isolates (C1, C2, C3, and C4). The microorganisms used in the study are clinically important pathogens which are causing several infections and food-borne diseases.

\section{Agar well diffusion assay}

In vitro antimicrobial activity of leaf, stem, and bark of $P$. santalinus was determined by agar well diffusion assay $[35,36]$. Mueller-Hinton agar (MHA) and sabouraud dextrose agar $\left(40-42^{\circ} \mathrm{C}\right)$ were seeded with $200 \mu \mathrm{l}$ of inoculums $\left(1 \times 10^{8} \mathrm{cfu} / \mathrm{ml}\right)$ and poured into Petri dishes. The media were allowed to solidify, and wells were prepared in the seeded agar plates with the help of a cup borer $(8.5 \mathrm{~mm})$. The plant parts extracts were dissolved in $100 \%$ dimethyl sulfoxide (DMSO) at a concentration of $20 \mathrm{mg} / \mathrm{ml}$, and from this, $100 \mu \mathrm{l}$ of extract was added into the well. The plates were incubated at $37^{\circ} \mathrm{C}$ and $28^{\circ} \mathrm{C}$ for 24 and 48 hrs for bacteria and fungi, respectively. DMSO was used as a negative control. Antibacterial activity was assayed by measuring the diameter of the zone of inhibition formed around the well in millimeters. The experiment was done in triplicate and the mean values are presented for antibacterial activity.

\section{Antibiotics used}

The antibiotics ampicillin (AMP), polymyxin-B $\left(\mathrm{PB}^{100}\right)$, clotrimazole $\left(\mathrm{CC}^{10}\right)$, and fluconazole $\left(\mathrm{FLC}^{10}\right)$ were purchased from Hi-Media Laboratory Pvt. Ltd., Mumbai, India.

\section{Agar disc diffusion assay}

Synergistic antimicrobial activity of $P$. santalinus with antibiotics (AMP, PB, CC, and FLC) was assessed against two Gram-positive bacteria, two Gram-negative bacteria, and two fungi using disc diffusion method [37]. The Petri plates were prepared by pouring $20 \mathrm{ml}$ of sterilized molten MHA for bacteria and $20 \mathrm{ml}$ Sabouraud dextrose agar for fungi, seeded with $200 \mu \mathrm{l}$ test culture containing $1 \times 10^{8} \mathrm{cfu} / \mathrm{ml}$ as McFarland 0.5 turbidity standard. Plates were allowed to solidify. Sterile filter paper discs $(6 \mathrm{~mm})$ were impregnated with $20 \mu \mathrm{l}$ of each plant extract separately. The antibiotic disc was impregnated with $20 \mu$ lof plant extract and allowed to saturate for 30 minutes and were placed on the surface of the agar plates which had previously been inoculated with test microorganisms. All the plates were incubated for $24 \mathrm{hrs}$ at $37^{\circ} \mathrm{C}$ for bacteria and for $48 \mathrm{hrs}$ at $30^{\circ} \mathrm{C}$ for fungi. Results were recorded by measuring the zone of inhibition appearing around the discs. All the tests were performed in triplicate, and the mean values are presented. DMSO was used as negative control.

\section{RESULTS AND DISCUSSION}

The extractive yield by decoction extraction method of different parts of P. santalinus is given in Fig. 1a and total phenol content in Fig. $1 \mathrm{~b}$. Maximum extractive yield was in stem, followed by leaf; bark had very less extractive yield (Fig. 1a). The extractive yield is different in different parts of the same plants, and it is also affected by the solvents and methods used for extraction [38]. All the three parts had almost same total phenol content (Fig. 1b). The extractive yield of bark was very much less than stem, but total phenol content was almost same like that of stem. Therefore, it can be stated that higher yield does not imply a higher level of activity and vice versa.

\section{Antimicrobial activity}

Antimicrobial activity of leaf, stem, and bark decoction extracts of P. santalinus against four Gram-positive bacteria, four Gram-negative bacteria, four fungi, and four clinical isolates is given in Fig. 2. The antibacterial activity against Gram-positive bacteria is given in Fig. 2a. The stem and bark extracts of P. santalinus inhibited all the four Grampositive bacteria. The leaf extract did not inhibit any bacteria. All the four bacteria were resistant to leaf extract. The stem extract showed slightly higher zone of inhibition as compared to the bark extract (Fig. 2a). The antibacterial activity against Gram-negative bacteria is given in Fig. $2 \mathrm{~b}$. 
The leaf, stem, and bark extracts of $P$. santalinus inhibited PA while EC and KP were inhibited by leaf and bark extracts. $S$. typhimurium was inhibited by stem and bark extracts (Fig. 2b). Among the three parts, bark extract showed best antibacterial activity, while leaf extract showed minimum activity. Among8 Gram-positive and Gram-negative organisms, PA was the most susceptible organism.

The antifungal activity of the three parts is given in Fig. 2c. The leaf, stem, and bark extracts of $P$. santalinus inhibited CA while CG was inhibited by leaf and stem extracts. $\mathrm{CN}$ and $\mathrm{CE}$ were inhibited by only stem extract (Fig. 2c). CA was the most susceptible fungal strain. The antifungal activity of the three parts against four clinical isolates is given in Fig. $2 \mathrm{~d}$. All the three extracts of $P$. santalinus inhibited the clinical isolate $\mathrm{C} 1$ while clinical isolates $\mathrm{C} 2, \mathrm{C} 3$, and $\mathrm{C} 4$ were inhibited by stem and bark extracts. They were resistant to leaf extract. Stem and bark extracts showed good antifungal activity (Fig. 2d).

Different parts of $P$. santalinus showed inhibition more against bacteria than fungi. The plant extracts showed slightly more antibacterial activity toward Gram-positive bacteria than Gram-negative bacteria. The bark extract showed best antibacterial activity followed by stem extract. There are two reasons for the differential activity of different parts of the same plant. The phytochemical compounds present in them may be different and also in different amounts. The inhibition level is different because the Gram-positive bacteria, Gram-negative bacteria, and fungi differ in their cell wall structure. The Gram-negative bacteria possess a tougher cell wall than Gram-positive bacteria and the fungi

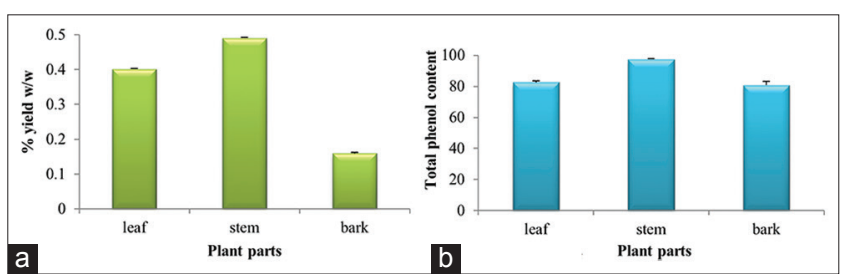

Fig. 1: (a) The extractive yield of different parts of Pterocarpus santalinus, (b) total phenol content of different parts of $P$. santalinus possess the toughest cell wall. The plant extracts generally inhibit Gram-positive bacteria as reported by many researchers [31,39-41]

\section{Synergistic antimicrobial activity}

Synergistic antimicrobial activity of different parts (leaf, stem, and bark) of $P$. santalinus is given in Figs. 3 and 4. P. santalinus leaf, stem, and bark extracts did not show inhibitory activity against all the four bacteria. AMP antibiotic showed inhibitory activity against SA and PA. PB antibiotic showed inhibitory activity against BC and PA. AMP antibiotic plus all the three parts extracts did not show inhibitory activity against all the four bacteria. PB antibiotic plus all the three parts extracts showed good inhibitory activity against all the four bacteria (Fig. 3). It appears that the plant extracts contain some phytocompounds that enhance the antibacterial efficacy of PB antibiotic, i.e. they work synergistically while they decrease the efficacy of AMP antibiotic.

Leaf, stem, and bark extracts of $P$. santalinus did not show antifungal activity against both the fungi. CC antibiotic alone showed inhibitory activity against both the fungi though the activity was more against CA. Unlike CC antibiotic, FLC antibiotic alone showed inhibition only against CN. The synergistic activity of stem and bark extract was slightly more than that of leaf extract. CC antibiotic plus leaf, stem, and bark extracts showed antagonistic activity against CA. FLC antibiotic plus all the extracts showed good synergetic activity against both the fungi. The stem and bark extracts showed better synergistic activity against both fungi than leaf extract (Fig. 4). In combination studies, both the antibiotics showed different activity. CC antibiotic with plant extracts showed antagonistic activity while FLC antibiotic with the same plant extracts showed synergistic activity against CA. Similar results, i.e., synergistic antimicrobial activity of plants extracts and antibiotics are also reported by others in literature [42-45]. The combination of plant extract with antibiotics can result in antagonistic or synergistic effect depending on the part of the plant used and the antibiotic used. The same plant extract may enhance the activity of some antibiotic while it may decrease the activity of another antibiotic. Similar results are reported in P. cincinnata [46]. It can also be stated that synergistic or combination therapy is a better option to tackle the problem of ever increasing drug resistance in bacteria and fungi $[43,47]$

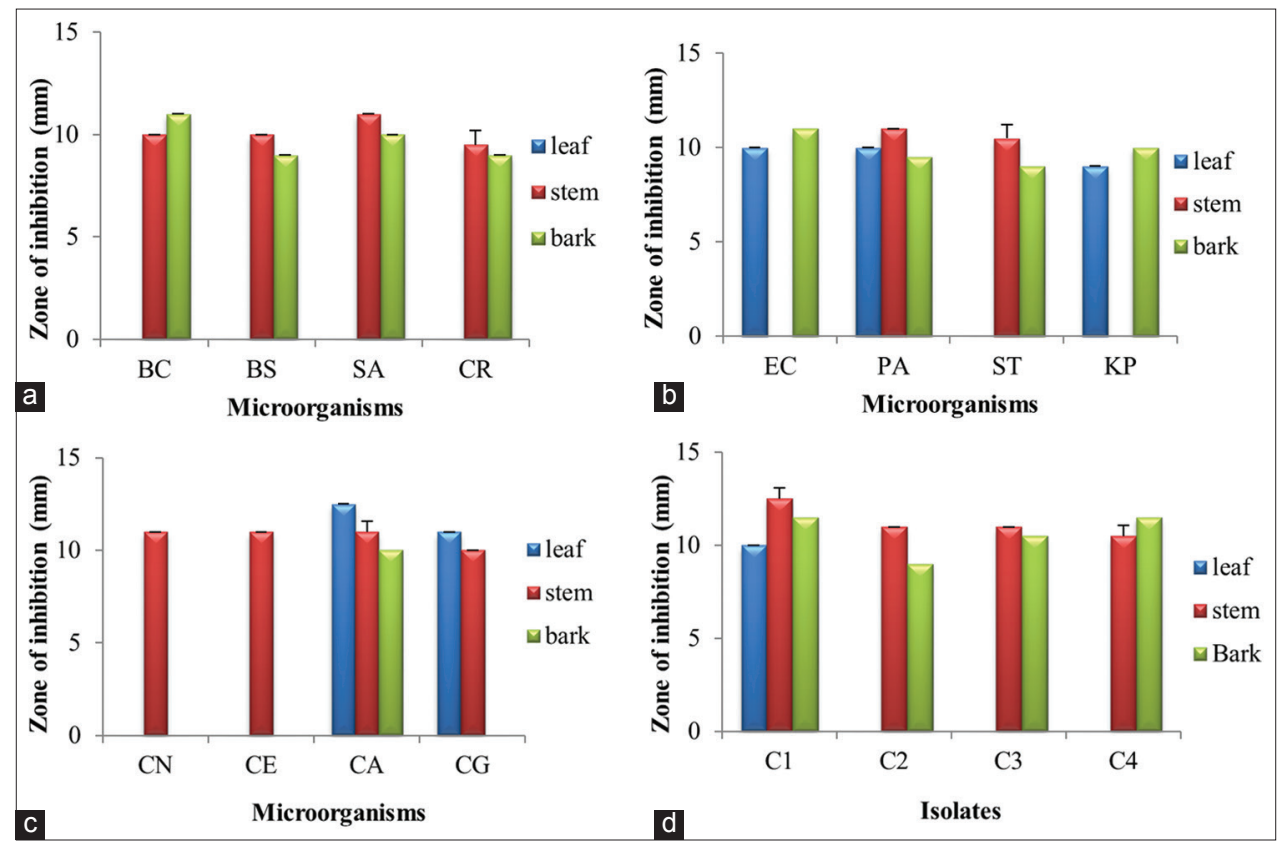

Fig. 2: Antimicrobial activity of different parts of Pterocarpus santalinus; (a) Gram-positive bacteria; (b) Gram-negative bacteria; (c) fungi; (d) clinical isolates 


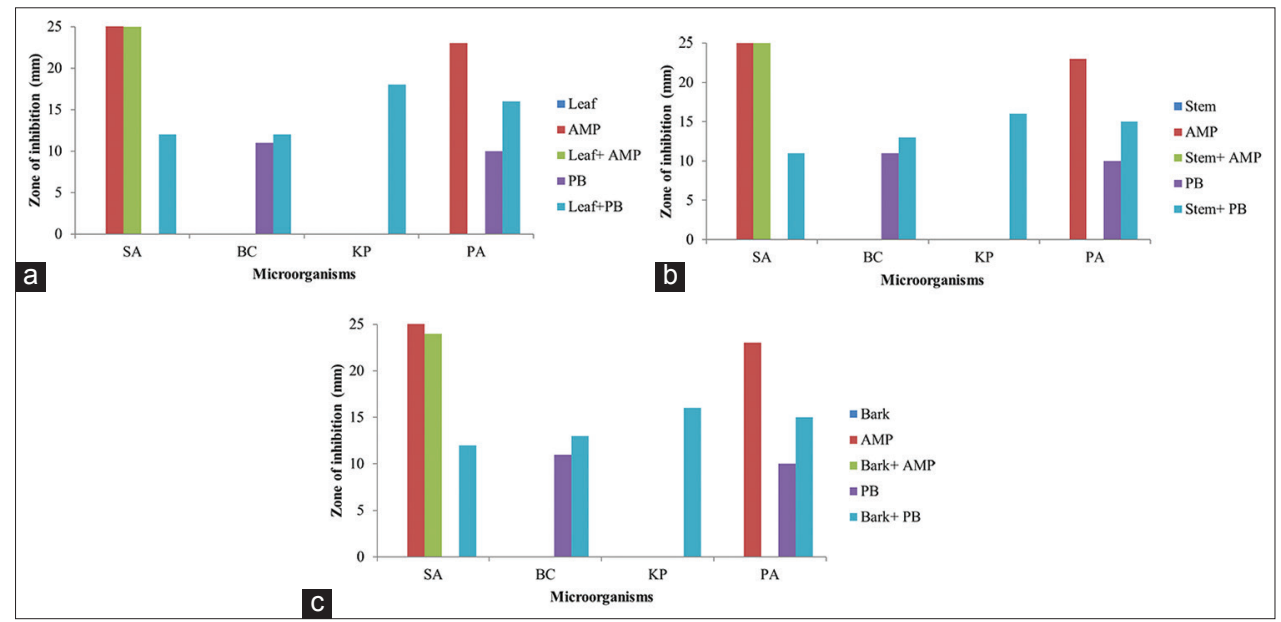

Fig. 3: Synergistic antimicrobial activity of Pterocarpus santalinus, (a) leaf, (b) stem, (c) bark against Gram-positive and Gram-negative bacteria

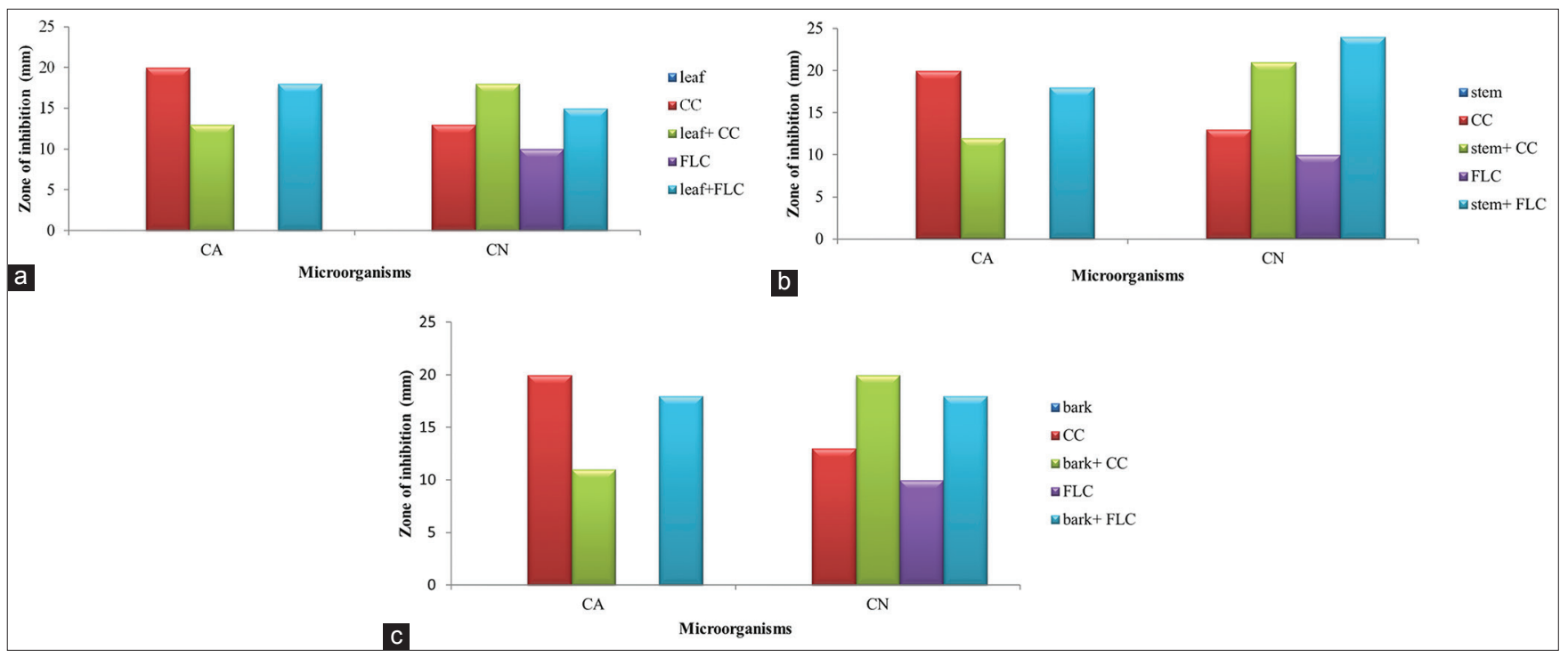

Fig. 4: Synergistic antimicrobial activity of Pterocarpus santalinus, (a) leaf, (b) stem, (c) bark against fungi

\section{CONCLUSION}

Plant extracts alone did not show any antimicrobial activity, but when combined with antibiotics, they showed synergistic antimicrobial activity. It can be emphatically stated that the three plant extracts possess some phytocompounds that enhance the antimicrobial efficacy of the antibiotics against some microorganisms. Hence, these plant extracts can be developed as a new therapeutic weapon against infectious diseases.

\section{ACKNOWLEDGMENTS}

The authors would like to thank the Department of Biosciences (UGCCAS) for providing excellent research facilities. One of the authors Ms. Pooja Moteiya is thankful to UGC, New Delhi, for providing meritorious Junior Research Fellowship.

\section{REFERENCES}

1. Herath HM, Chamikara MD, Dissanayake DR, Dissanayake MD, Ishan $\mathrm{M}$, Rajapakse $\mathrm{S}$, et al. A comparative assessment of the antibacterial activity in fruit juice of Sri Lankan sweet orange cultivars vis-a-vis sour orange. J Agric Sci 2016;11(1):13-23

2. Kraft K. Complementary/alternative medicine in the context of prevention of disease and maintenance of health. Prev Med 2009; $49(2-3): 88-92$
3. Mukherjee PK, Wahile A. Integrated approaches towards drug development from Ayurveda and other Indian system of medicines. J Ethnopharmacol 2006;103(1):25-35.

4. Shahad EH, Shahwany AW. Increasing antimicrobial activity of some plant extracts against antibiotic resistant Staphylococcus aureus by using silver nanoparticles. World J Exp Biol 2016;4(1):7-14.

5. Higashiguchi F, Nakamura H, Hayashi $H$, Kometani T. Purification and structure determination of glucosides of capsaicin and dihydrocapsaicin from various Capsicum fruits. J Agric Food Chem 2006;54(16):5948-53.

6. Cowan MM. Plant products as antimicrobial agents. Clin Micbiol Rev 1999; 12:564-82.

7. Lewis K, Ausubel FM. Prospects for plant-derived antibacterials. Nat Biotechnol 2006;24(12):1504-7.

8. Overbye KM, Barrett JF. Antibiotics: Where did we go wrong? Drug Discov Today 2005;10(1):45-52.

9. Granados CA, Cardo DM, McGowan JE Jr. Antimicrobial resistance: International control strategies, with a focus on limited-resource settings. Int J Antimicrob Agents 2008;32:1-9.

10. Anjaria J, Parabia M, Dwivedi S. Ethnovet Heritage-Indian Ethno Veterinary Medicine an Over View. Ahmedabad, India: Pathik Enteprise; 2002.

11. Malini M, Abirami G, Hemalatha V, Annadurai G. Antimicrobial activity of ethanolic and aqueous extracts of medicinal plants against waste water pathogens. Int J Res Pure Appl Microbiol 2013;3(2):40-2.

12. Ertas A, Boga M, Gazioglu I, Yesil Y, Hasimi N, Ozaslan C, et al. Fatty acid, essential oil and phenolic compositions of Alcea pallida and Alcea 
apterocarpa with antioxidant, anticholinesterase and antimicrobial activities. Chiang Mai J Sci 2016;43:1143-53.

13. Hasanshahian M, Khosravi F. Study the anti-microbial effects of Artemisia santonica extract on some pathogenic bacteria. Adv Herb Med 2015;1(4):43-6.

14. Nath K, Bhattacharya MK, Sen A, Kar S. Antibacterial activity of frond extract of Asplenium nidus L. threatened ethno-medicinal fern of north east India. Int J Pharmacogn Phytochem 2013;28(2):2051-8.

15. Gayathri N, Gopalakrishnan M, Sekar T. Phytochemical screening and antimicrobial activity of Capsicum chinense Jacq. Int J Adv Pharm 2016;5(1):12-20.

16. Abraham J, Thomas TD. Antibacterial activity of medicinal plant Cyclea peltata Hooks and Thoms. Asian Pac J Trop Dis 2012;2(1):S280-4.

17. Doley P, Jha DK. Antimicrobial activity of bacterial endophytes from medicinal endemic plant Garcinia lancifolia Roxb. Ann Plant Sci 2015;4(12):1243-7.

18. de Rapper S, Kamatou G, Viljoen A, van Vuuren S. The in vitro antimicrobial activity of lavandula angustifolia essential oil in combination with other aroma-therapeutic oils. Evid Based Complement Alternat Med 2013;2013:852049.

19. Sen A, Batra M. Evaluation of antimicrobial activity of different solvent extracts of medicinal plant Melia azedarach L. Int J Curr Pharm Res 2012;4(2):67-73

20. Gond SK, Mishra A, Sharma VK, Verma SK, Kumar J, Kharwar RN, et al. Diversity and antimicrobial activity of endophytic fungi isolated from Nyctanthes arbortristis, a well-known medicinal plant of India. Mycoscience 2012. DOI: 10.1007/s10267-011-0146-z.

21. Akinsanya M, Goh JK, Lim SP, Ting AS. Biodiversity, enzymatic and antimicrobial activities of bacterial endophytes in selected local medicinal plants. J Biol Pharm Res 2015;5(1):76-88.

22. Kaur M, Aggarwal NK, Dhiman R. Antimicrobial activity of medicinal plant Parthenium hysterophorus L. Res J Med Plans 2016. DOI: $10.3923 /$ rjmp.

23. Vandita P, Amin N, Khyati P, Monisha K. Effect of phytochemical constituents of Ricinus communis, Pterocarpus santalinus, Terminalia bellerica on antibacterial, antifungal and cytotoxic activity. Int J Toxicol Pharm Res 2013;5(2):47-54

24. Rao ML, Savithramma N. Antimicrobial activity of silver nanoparticles synthesized by using stem extract of Svensonia hyderobadensis (Walp.) mold-a rare medicinal plant. Res Biotechnol 2012;3(3):41-7.

25. Shrestha P, Bista M, Sharma P, Shrestha S, Lamichhane B, Adhikari S, et al. Phytochemical screening, antimicrobial activity and cytotoxicity of Nepalese medicinal plants Swertia chirayita and Dendrobium amoenum. Nepal J Biotechnol 2015;3(1):48-54.

26. Gawai D, Das G, Rout GR. Phytochemical screening and comparative analysis of antimicrobial activity of root and leaf extracts of Tinospora coridifolia, Phyllanthus niruri and Abrus precatorious, important medicinal plants. J Med Plants Res 2013;7(29):2208-13.

27. Chanda S, Rakholiya K, Dholakia K, Baravalia Y. Antimicrobial, antioxidant and synergistic properties of two nutraceutical plants: Terminalia catappa L. and Colocasia esculenta L. Turk J Biol 2012;37:81-91.

28. Karunai Raj M, Balachandran C, Duraipandiyan V, Agastian P, Ignacimuthu S. Antimicrobial activity of Ulopterol isolated from Toddalia asiatica (L.) Lam.: A traditional medicinal plant. J Ethnopharmacol 2012;140(1):161-5.

29. Bindu A, Rosemary J, Akhila S. Antimicrobial activity screening of
Marselia minuta extracts. Int J Pharm Pharm Sci 2014;6(10):581-3.

30. Hishobkar SW, Urolagin DK, Ashish C, Maski S. Evaluation of synergestic antimicrobial effect of Anogeissus latifolia and Glycerrhiza glabra extract. Int J Pharm Pharm Sci 2010;2(4):158-9.

31. Hussain A, Zaman MK, Ramteke AM. Antibacterial activity of trunk bark of Alstonia cholaris. Asian J Pharm Clin Res 2010;3(4):46-7.

32. Pawar NK, Arumugam N. Leaf extract of Centratherum punctatum exhibits antimicrobial, antioxidant and anti-proliferative properties. Asian J Pharm Clin Res 2011;4(3):71-6.

33. Li HB, Jiand Y, Wong CC, Cheng KW, Chen F. Evaluation of method for the extraction of antioxidants from medicinal plants. Anal Bioanal Chem 2007:388:483-8

34. McDonald S, Prenzler PD, Antolovich M, Robards K. Phenolic content and antioxidant activity of olive extracts. Food Chem 2001;73(1):73-84.

35. Perez C, Paul M, Bazerque P. An antibiotic assay by the agar well diffusion method. Acta Biol Med Exp 1990;15:113-5.

36. Chanda S, Rakholiya K, Parekh J. Antimicrobial efficacy of Mesua ferrea $\mathrm{L}$. Seed extracted in different solvents against infection causing pathogenic strains. J Acute Dis 2013;2(4):277-81

37. Rakholiya $\mathrm{K}$, Chanda S. In vitro interaction of certain antimicrobial agents in combination with plant extracts against some pathogenic bacterial strains. Asian Pac J Trop Biomed 2012;2(2):S876-80.

38. Kaneria MJ, Bapodara MB, Chanda SV. Effect of extraction techniques and solvents on antioxidant activity of pomegranate (Punica granatum L.) leaf and stem. Food Anal Method 2012;5:396-404.

39. Parekh J, Chanda S. In vitro antibacterial activity of the crude methanol extract of Woodfordia fruticosa Kurz. Flower (Lythraceae). Braz J Microbiol 2007;38:204-7.

40. Bajpai VK, Na M, Kang SC. The role of bioactive substances in controlling food borne pathogens derived from Metasequoia glyptostroboides Miki ex Hu. Food Chem Toxicol 2010;48:1945-9.

41. Agullo FA, Pereira E, Freire MS, Valentao P, Andrade PB, Gonzalez-Alvarez $\mathrm{J}$, et al. Influence of solvent on the antioxidant and antimicrobial properties of walnut (Juglans regia L.) green husk extracts. Ind Crops Prod 2013;42:126-32.

42. Drago L, de Vecchi E, Nicola L, Gismondo MR. In vitro evaluation of antibiotics' combinations for empirical therapy of suspected methicillin resistant Staphylococcus aureus severe respiratory infections. BMC Infect Dis 2007;7:111.

43. Choi JG, Choi JY, Mun SH, Kang OH, Bharaj P, Shin DW, et al. Antimicrobial activity and synergism of Sami-Hyanglyun-Hwan with ciprofloxacin against methicillin-resistant Staphylococcus aureus. Asian Pac J Trop Med 2015;8(7):538-42.

44. Rakholiya $\mathrm{KD}$, Kaneria MJ, Chanda S. In vitro assessment of novel antimicrobial from methanol extracts of matured seed kernel and leaf of Mangifera indica L. (Kesar mango) for inhibition of Pseudomonas spp. and their synergistic potential. Am J Drug Discov Dev 2015;5(1):13-23.

45. Padalia H, Chanda S. Antimicrobial efficacy of different solvent extracts of Tagetes erecta L. flower, alone and in combination with antibiotics. Appl Microbiol 2015. DOI: 10.4172/2471-9315.1000106.

46. Siebra AL, Oliveira LR, Martins AO, Siebra DC, Albuquerque RS, Lemos IC, et al. Potentiation of antibiotic activity by Passiflora cincinnata Mast. Front of strains Staphylococcus aureus and Escherichia coli. Saudi J Biol Sci 2016. In Press.

47. McConeghy KW, Bleasdale SC, Rodvold KA. The empirical combination of vancomycin and a beta-lactam for Staphylococcal bacteremia. Clin Infect Dis 2013;57(12):1760-5. 